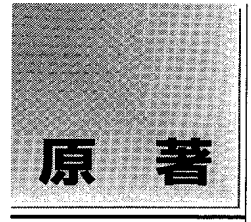

\section{イメージングプレート $(\mathbf{C R})$ の基本的な物理特性}

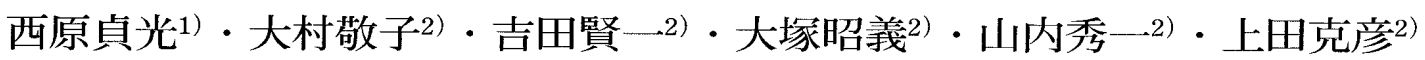

1 )山口大学医学部附属病院放射線部

現 広島県立保健福祉短期大学放射線技術科学科

2)山口大学医学部附属病院放射線部

\section{1. はじめに}

FCRシステムが登場して10年以上経過し, 装置も FCR 101からFCR 9000 となって多くの改良がなされて きた，大きな改良点は，三点あり，一つはFCR 7000か ら搭載されたEDR処理である。これによって, 撮影 条件設定ミスが大幅に減少し, 安定した画像が得られ るようになった1). またFCR 9000では，ニューラル。 ネットワーク技術を利用した新しい処理とダイナミッ クレンジ $(\mathrm{DR})$ 圧縮処理が導入された。これら新技術 の導入によって, 従来のヒストグラム解析による方法 では画像の安定供給が困難であった部位についても安 定性が向上し, さらに, 広い診断領域を 1 枚のフィル ム上に可視化(再現)することが可能となった

以上のように装置本体の改良には目ざましいものが
ある。同時にCRの検出器であるイメージングプレー 卜 (以下, IP)についてもHR (マンモグラフィ専用), $\mathrm{ST}$ (一般撮影用) 双方について, I 型から V 型へと改 良，变遷がなされてきた。

これらIPのI型から III 型についてはすでに物理特性 が測定され，報告も行われている3,99. 例えば，IP固有 の感度と思われる輝尽発光量については，I型から III 型まで大幅に増加していたが，解像特性(プリサンプ リング $\left.\mathrm{MTF}^{4)}\right)$ はほとんど変化しておらず，粒状特性 (ディジタルウィナースペクトル5) は若干改善されて いた。また， 3 種類のFCRシステムと各IPの組合せを 変えて物理特性を測定した報告もある6). しかし, IP 固有の物理特性に関する報告は他にあまり見られな w.

\title{
Basic Imaging Properties of Imaging Plates in a Computed Radiography System
}

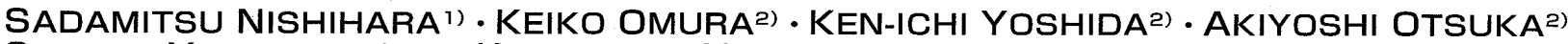 SYUICHI YAMAUCHI ${ }^{2)}$ and KATSUHIKO UEDA ${ }^{2)}$}

1) Department of Radiology, Yamaguchi University Hospital

Present address: Department of Radiological Sciences and Technology, Hiroshima

Prefectural College of Health and Welfare

2) Department of Radiology. Yamaguchi University Hospital

Received Jun.7,1996; Revision accepted Aug.23,1996; Code No.254,532,814

\section{Summary}

We measured basic imaging properties like dose attenuation ratio, photostimulated emission, resolution property (presampling MTF: MTFPRE) and noise property (digital Wiener spectrum: WS DIG $_{\text {) }}$ using various versions of HR and ST imaging plates. Resolution property was almost the same for three respective versions of the HR and ST plates. The photostimulated emission of HR III $\mathrm{N}_{\mathrm{N}}$ was higher than that of III and V by about $50 \%$ and $20 \%$, respectively. The noise property of HR V was superior to that of other plates. In terms of the photostimulated emission of ST plates, there was no difference between III and III N, however, that of V was about $10 \%$ higher than that of other plates. The noise property of ST V was superior to that of III N. ST III has a different type of structure mottle than versions III $\mathrm{N}$ and $\mathrm{V}$. 
CRシステムを一旦購入すると, 本体についてはな かなか取り替えることができないが，IPについては簡 単に入视えが可能である。したがってCRシステム を使用する上で, IPの基本的な性能を把握しておくこ とは非常に重要だと考える。そこで，今回HR，STシ リーズについて，そ狆ぞれIII 型以降の基本的な物理特 性を測定したので報告する。

\section{2. 使用萿雷と实强方法}

使用したIPは，HR，STともにIII 型，IIIN型，V型 の3 種類である.HRは 6 切サイズだけであるが，ST には 6 切の他に 4 切, 大角, 半切がある. サイズが 違うと，データを読み取るときの+ンプリング間隔が 異なるので, プリサンプリングMTFやディジタルウィ ナースペクトルが変化する。 そのため, 今回使用する IPサイズは，全て 6 切の大きさ(サンプリング間隔は $0.1 \mathrm{~mm}) に$ 統一した。

IPの読み取りに使用したCR装置は，FCR 101であ る。この装置の読み取り部には, He-Neレーザが使用 されている. III, III N型 (BaFBr：Eu蛍光体)はこのレ 一ザの波長 $(633 \mathrm{~nm})$ に対応しているが，V型 $(\mathrm{BaF}(\mathrm{Br}$, I）：Eu蛍光体)は，輝尽励起波長のピークがIII， IIIN 型より少し長波長側に移動している2!。こ礼はFCR 9000 に使われている可視光半導体レーザの波長 $(680 \mathrm{~nm})$ とのマッチングを考えた結果と推測される。

今回，測定したのは次の5項目である。

1) 照射線量減弱率 (IPによって吸収された照射線量 の割合)

2) 輝尽発光量

3) 解像特性 (プリサンプリングMTF)

4) 粒状特性(ディジタルウィナースペクトル：ディ ジタルWS)

以下，そ妃ぞ机の方法について述べる.

\section{2-1 照射線量減弱率}

照射線量減弱率とはIPに入射した線量のうち，IPに よって吸収された線量の割合を意味する。他の文献に は吸収線量率 ${ }^{3} や X$ 楾吸収率となっているものもある が, 䀺密にはIPか吸収した線量だけではなく, 他の要 因によって減弱された線量も含んで測定している。し たがって，今回は照射線量減弱率という名称を使用す 子.

X線管-娭出器 (線量計 : radcal mdh 1015c) 間距離を $135 \mathrm{~cm}$ として，この中間(約 $80 \mathrm{~cm}$ こころ)にIPを配置 した。IPを配置する前と後の線量を測定して，IPによ る線量隇弱率を求めた。

\section{2-2 輝尽発光量}

輝尽発光とは，レーザ光をIPに照射したとき，蓄積 されたX線エネルギに応じて発光する光のことであ る. 輝尽発光はIPがエネルギを蓄積し, 発光する性能 に依存しており，この光量を測定することでIP固有の 感度を解析できる。

X線エネルギに応じた輝尽発光量を得るため, 距離 法を用いて各IPの特性曲線を測定した。管電死は 1996 年 11 月
$80 \mathrm{kV}$ とし, $0.5 \mathrm{~mm}$ 厚の銅と $4 \mathrm{~mm}$ 厚のアルミニウムを フィルタとして同時に付加した．III 型のIPが基準とな るように他のIPと組合せて (III と IIIN型，III と V 型の 組合せ), 同時露光した.

CR装置での読み取りモードをL值：2.0とし，E值 (FCR 101以外はS值という)を200に固定した。

読み取ったディジタルデータをパーソナルコンピュ 一タに転送し7，ディジタル值が127となるときの比露 光量の逆数を輝尽発光量の值とした。またこのとき, 各シリーズの III 型を基準とした相対值で評価した。

\section{2-3 解像特性(プリサンプリングMTF)}

本実験の目的は，各IPによる解像特性の違いをみる ことであるため，プリサンプリングMTFを測定した。

アナログシステムと同様に幅 $10 \mu \mathrm{m}$ のスリットを使用 してスリット像を作成した。このとき，スリットの幅 に対して少し角度をつける(スリットに対してIPの長 軸または短軸を斜めにする)ことでセンターアライメ ント時からシフテッドアライメント時までの多くのデ ータを得ることができる。このデータをパーソナルコ ンピュータに転送し，藤田らの方法4を用いてプリサ ンプリングMTFを算出した。

\section{2-4 粒状特性(ディジタルWS)}

粒状特性については，ディジタルWS 51 を測定した。 WS 試料の作成には，X線管とIP間を $260 \mathrm{~cm}$ 以上と し，X線管の絞り部分に20mm厚さのアルミニウムフ イルタをとりつけた。管電压を $80 \mathrm{kV} と し て \mathrm{mAs}$ 值を 変化させることで, IP入射線量を $0.13 \mu \mathrm{C} / \mathrm{kg}(0.5 \mathrm{mR})$ から $3.9 \mu \mathrm{C} / \mathrm{kg}(15 \mathrm{mR})$ まで変化させた。これは各 $\mathrm{IP} の$ 照射線量に対するディジタルWSの変化を求めるため である。

読み取りモードは，L值が2.0固定でE值が変化する セミオートモードを使用した。さらに各IPの構造モト ル(structure mottle)を検討するため，X線量子モトル の影響がほぼ無視できるほどの線量 (約 $2.5 \mu \mathrm{C} / \mathrm{kg}$ $(10 \mathrm{mR}))$ を照射したときのディジタルWSを比較し た.しかし，IPによっては，約 $2.5 \mu \mathrm{C} / \mathrm{kg}(10 \mathrm{mR})$ か 線量子モトルを完全に無視できる程度の線量とはいえ ない可能性もある。したがって今回は，各IPの構造モ トルの形状と相対的な関係を検討することとした。

1024x1024ピクセルの面積データを1×30ピクセルご とに分割し，そのデータをフーリエ変換して，合計 1024点x34本のディジタルWSを算出した5).

\section{3. 结果と教尨}

\section{3-1 照射線量減弱率と輝尽発光量}

各IPの照射線量減弱率と輝尽発光量をTableに示 के.

IPの線量減弱率は，アナログシステムにおける増感 紙と同様に，IPを構成する輝尽性监光体の粒子径や充 填密度, 蛍光体層の厚さなどに依存すると考えられ る.

HRシリーズについて減弱率をみると，III 型に対し 
て，IIIN型は約 $10 \%$ 高くなっているが，逆にV型では 約7\%低くなっている。この值が高いほとX線の吸収 効率が向上するため，X線量子モトルの影響は低くな ると予想される。したがって，IPへの入射線量が少な く，X線量子モトルの影響が高いと予想されるときの 粒状特性を比較すると，V型の粒状性が一番悪く， IIIN型が一番良くなる可能性がある。ただし，これは 構造モトルなど他の粒状特性が同一の場合にいえるこ とであり，実際の粒状特性については，3-3-1で後述 する.

輝尽発光量を比較すると， IIIN型は III 型の約 1.5 倍, $\mathrm{V}$ 型は䄪1.2倍となっている. III と V 型については線 量減弱率のときと逆の関係を示している。すなわち, $\mathrm{V}$ 型は山型に対してX線の吸収が少ない(照射線量減弱 率が約7\%低い)にもかかわらず，楎尽発光量は多くな っていた。

STシリーズの線量減弱率を比較すると，III，IIIN型 はほほ同じ值であり，V型だけ約10\%高くなった。し たがって，X線量子モトルの影響はV型が一番低くな る可能性がある。この結果は3-3-2で述べる．楎尽発 光量と照射線量減弱率の傾向は同じであった。

\section{3-2 解像特性(プリサンプリングMTF)}

各IPのプリサンプリングMTFをFig.1に示す.

HR，STともにIII，IIIN，V 型による違いはほとん ど見られない。これは，各IPに対して，解像特性を一 定に保ちながら，その他の特性，例えば粒状特性や搬 送特性を改良しているのではないかと推測される。

CRシステムの解像特性には，いろいろな表現方法 がある.プリサンプリングMTFは，IP自体とサンプ リングアパーチャ(サンプリング間隔に依存する)の 不悦を表わしたものである4!。この他にディジタル MTFやデイスプレイMTF (デイスプレイ部の解像特 性を表す)，最終的にフィルム表示された画像に対す る総合的な解像特性を表すオーバーオールMTFなど

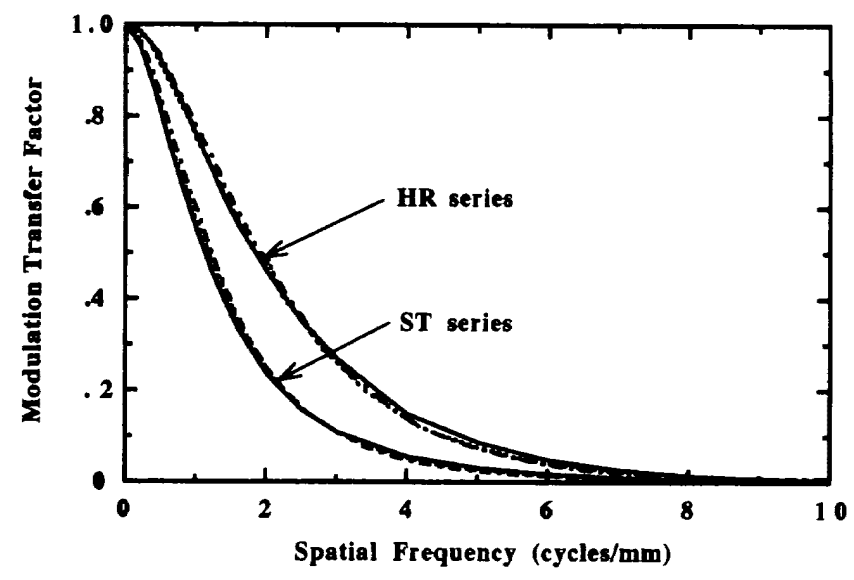

Fig. 1 Presampling MTFs for three versions of HR and ST imaging plates.

HR III : ( - ), HR IIIN $:(\cdots \cdots)$, HR V : ( - ST III : (- $)$, ST IIIN : ( …), ST $\vee:(-\cdots)$
がある8-10!.ただし，ディジタルMTFやオーバーオ 一ルMTFにはデー夕取り込み時に生じるエリアシン グ効果が含まれるため，画像の位置によって解像特性 が異なってくる。したがって，これらのMTFは解像特 性を正確に表わさないので注意が必要である3,8.9)。そ こでオーバーオールMTFに対してファイナルMTFと いう考え方も登場したが11，今のところ統一されてい ない.

またスリット法ではなく，矩形波チャート法を用 いてファイナルMTFを測定した発表などもあり12)，工 リアシング効果を取り除くためにいろいろな努力がな されている。

将来, CRシステムのようなディジタルシステムが 臨床の場で中心的な役割を持つであろうと考えると， 解像特性の評価法について改めて討論する必要があろ j.

\section{3-3 粒状特性(ディジタルWS)}

3-3-1 HRシリーズについて

照射線量とディジタルWSの関係をFig.2に示す。空 間周波数 $0.3 \mathrm{cycle} / \mathrm{mm}$ と $3.0 \mathrm{cycles} / \mathrm{mm}$ をパラメータに とったときのWSである。III型は0.3，3.0cycles $/ \mathrm{mm}$ のいずれの周波数においても IIIN, V 型より值が高く なっている，IIIN型とV型の関係をみると，X線量子 モトルの影響をほぼ無視できる線量(約 $2.5 \mu \mathrm{C} / \mathrm{kg}$ (約 $10 \mathrm{mR})$ 以上) を照射したときには，V型のほうがIIIN型 よりウィナースペクトル(WS)值が低い。これはV 型 の構造モトルがIIIN型より低いことを意味する。しか し，照射線量が比較的少ないときにはほほ同等のWS 值を示している。これは，V型の構造モトルが低いに もかかわらず，線量減弱率が IIIN型より低いため (Table参照)，X線量子モトルの影響をより多く受けて しまうためと考える。

IP入射線量が約 $2.5 \mu \mathrm{C} / \mathrm{kg}$ (約 $10 \mathrm{mR})$ のきのディジ タルWSをFig.3に示す。これはほほIPの構造モトルに 近い値を表していると考えられる。III型のモト ルが一番高く，IIIN，V型の順に低くなってい る.これは輝尽性蛍光体の粒子径や蛍光体層の 充填密度などに起因すると考える。

HRシリーズを使用する主な部位は乳房部(マ ンモグラフィ：mammography)であり，実際上， IP (または増感紙フィルム系)に入射する線量は $1 \sim 2.5 \mu \mathrm{C} / \mathrm{kg}(4 \sim 10 \mathrm{mR})$ 程度である。したがっ て，このような高線量を使用するときには，X線 の吸収効率 (照射線量減弱率) は高いが構造モ卜 ルも高いIIIN型より，吸収効率は少し低いが構造 モトルの優れているV 型を用いるほうがよいこ とになる。

近年では乳癌の増加に伴い，マンモグラフィ の件数が増える傾向にある。したがって，患者 被曝線量の観点から考えると，ディジタルシス テムを使用したときの照射線量と画質(診断)と の関係を詳細に検討する必要がある。また，可 能な限り線量を低くする必要性から，IPも低線 
量での粒状特性が優れたものを期待する.

3-3-2 STシリーズについて

Fig.4に照射線量とディジタルWSの関係を示 す。パラメータはHRと同様である。 0.3 cycle/ $\mathrm{mm}$ ではIII 型と V 型はほほ同等の值となってい るのに，3.0cycles/mmになると III 型のWS值が 一番高く，線量が増えるにしたがって他のIPと の差が開いている。これらのことから III 型は明 らかに他のIPとは違った構造モトルを有してい る可能性がある。

III $\mathrm{N}$ と V 型を比較すると, 0.3 cycle $/ \mathrm{mm}$ では III Nの值が高く，線量が増加するにつれて両者 の差が開いている。しかし，3.0cycles/mmでは 両者の值はほぼ同等となっている.

$\mathrm{ST}$ シリーズについて, $\mathrm{HR}$ 同様に約 $2.5 \mu \mathrm{C} /$ $\mathrm{kg}(10 \mathrm{mR})$ を照射したときのディジタルWSを Fig.5に示す.Fig.4で推測したように，III 型の構 造モトルは他のIPと異なった形状を示し，空間 周波数が約 2.0 cycles $/ \mathrm{mm}$ 付近で值が大きく上っ ている。これは，この大きさの蛍光体粒子が他 のものより多く含まれているためではないかと 推測している.

一般撮影用であるSTシリーズは，X線量子モ トルが主となる線量域で使用することがほとん どである。したがって，患者被曝線量を低減す るためには，できる限りX線の吸収効率が高いV 型のようなIPを使用する必要があると考える。 また, 一般撮影時に被写体がもつ周波数帯域(被 写体スペクトル)は比較的, 低·中空間周波数域 にあるといわれている13.14．Fig.4に示したよう に, V 型の 0.3 cycle $/ \mathrm{mm}$ でのWS值は入射線量が

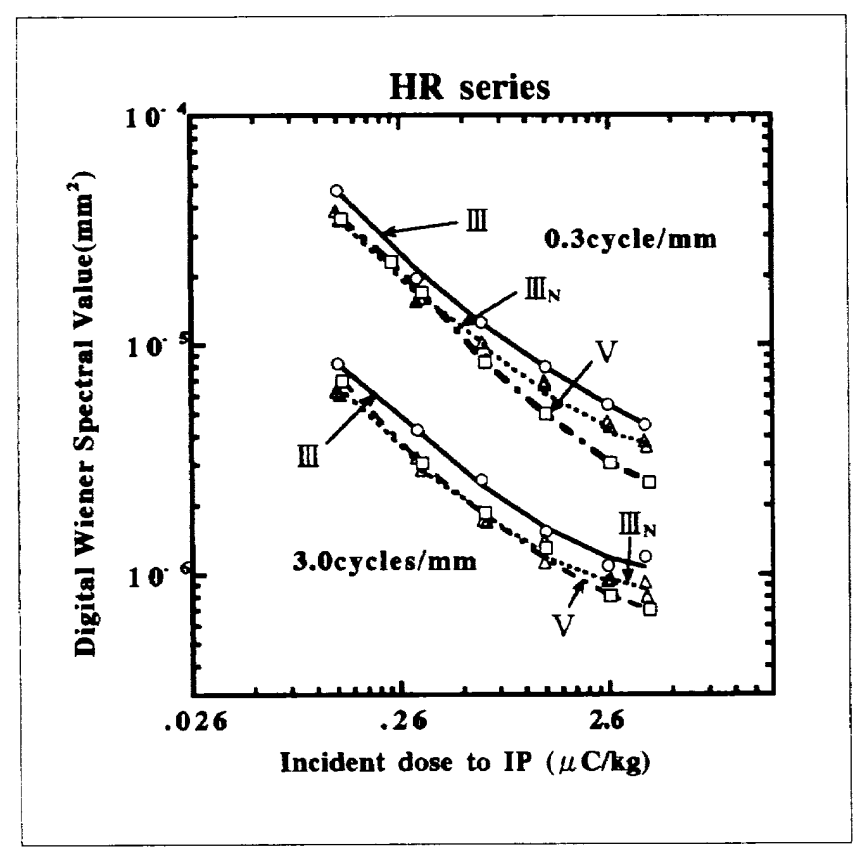

Fig. 2 Relation of digital Wiener spectral values to spatial frequencies of 0.3 and 3.0 cycles $/ \mathrm{mm}$ and incident dose to HR imaging plate.
Table Measured properties of three versions of HR and ST imaging plates.

(HR III, HR IIls, HR V, ST III, ST Illw and ST V).

Values in parentheses represent the relative value against type III HR and ST.

\begin{tabular}{|c|c|c|c|c|c|c|}
\hline & \multicolumn{3}{|c|}{ HR series } & \multicolumn{3}{|c|}{ ST series } \\
\hline & III & IIII & V & III & III $_{N}$ & V \\
\hline $\begin{array}{l}\text { Exposure } \\
\text { Attenuation } \\
\text { Ratio }[\%]\end{array}$ & $\begin{array}{r}31.7 \\
(100.0)\end{array}$ & $\begin{array}{c}35.0 \\
(110.4)\end{array}$ & $\begin{array}{c}29.2 \\
(92.7)\end{array}$ & $\begin{array}{r}44.7 \\
(100.0)\end{array}$ & $\begin{array}{r}44.9 \\
(100.4)\end{array}$ & $\begin{array}{c}49.5 \\
(110.7)\end{array}$ \\
\hline $\begin{array}{l}\text { Relative Intensity } \\
\text { of Photostimulated } \\
\text { Emission }\end{array}$ & 100.0 & 148.7 & 121.0 & 100.0 & 100.0 & 107.2 \\
\hline
\end{tabular}

$80 \mathrm{kV}$ with $20 \mathrm{mmAl}$

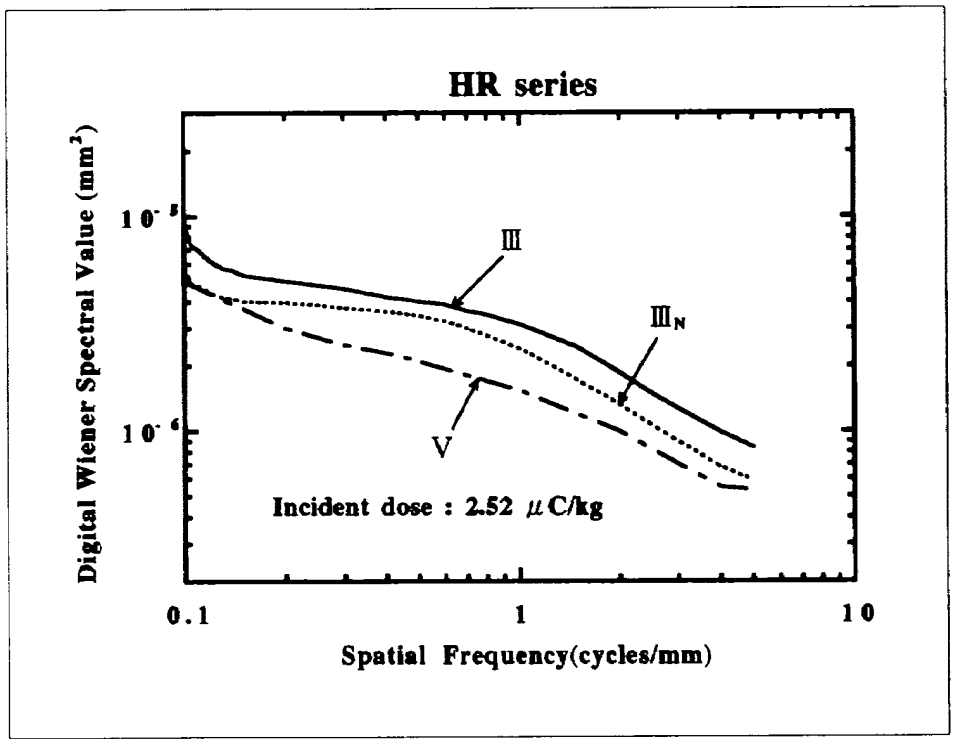

Fig. 3 Digital Wiener spectra for three versions of the HR imaging plate (III, IIIN and V).

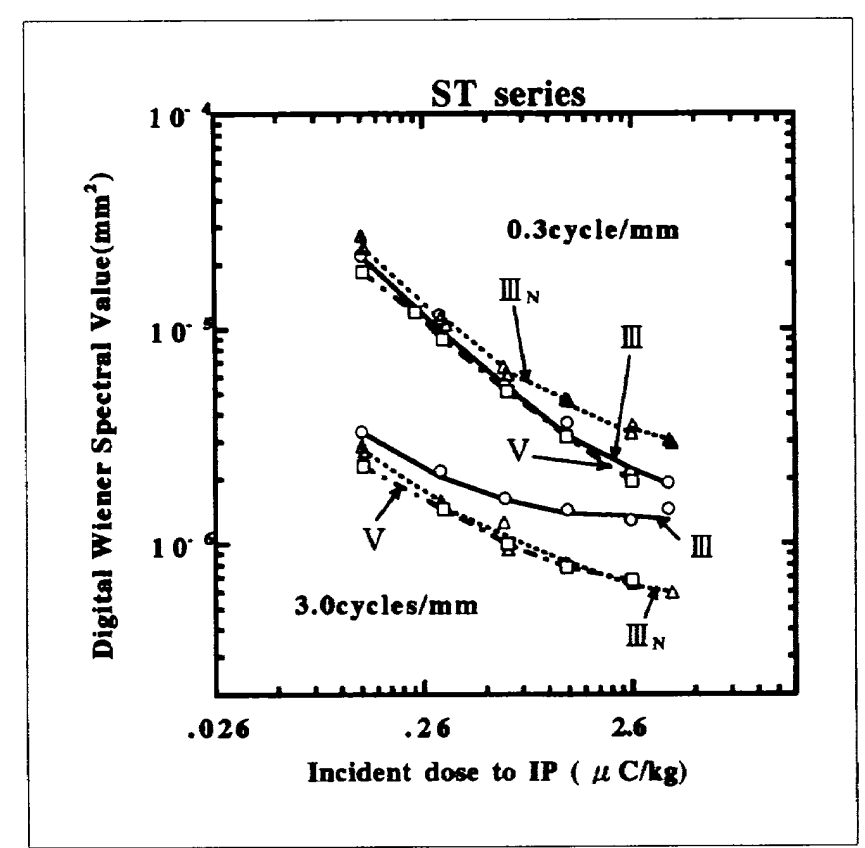

Fig. 4 Relation of digital Wiener spectral values to spatial frequencies of 0.3 and $3.0 \mathrm{cycles} / \mathrm{mm}$ and incident dose to ST imaging plate. 


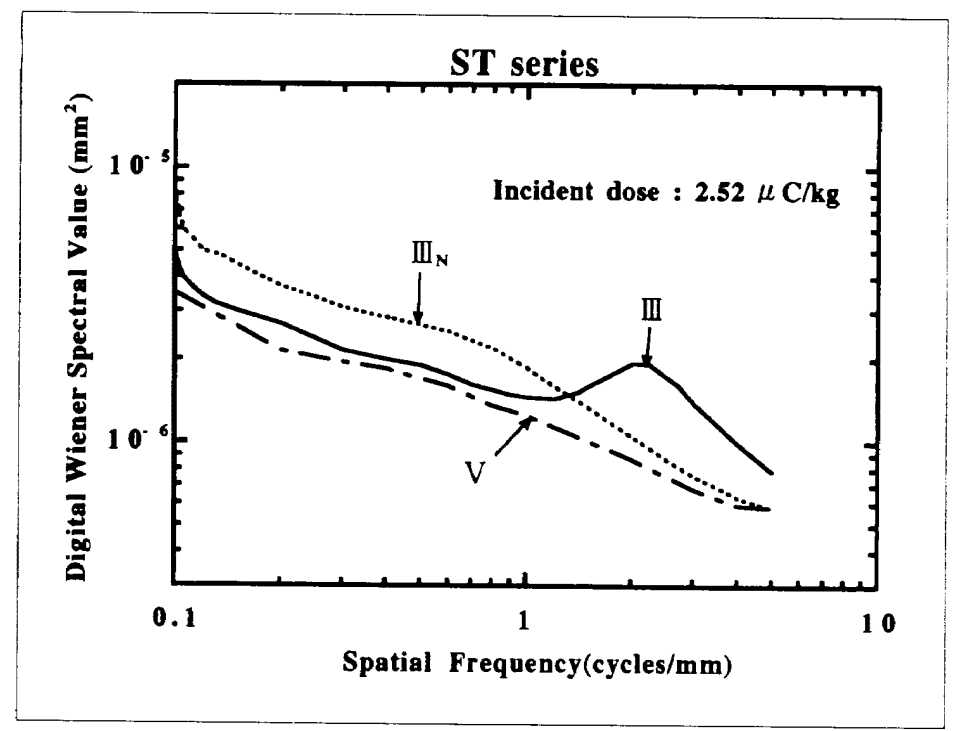

Fig. 5 Digital Wiener spectra for three versions of the ST imaging plate (III, IIIN and V).

$0.13 \sim 1.3 \mu \mathrm{C} / \mathrm{kg}(0.5 \sim 5.0 \mathrm{mR})$ の間において IIIN型より 16〜32\%低い. したがって，ノイズ特性から考えても 臨床にはV 型のIPを使用する方が有利と考える。

ただし，本実験で注意すべきことは，以上の結果が すべてFCR 101 で測定されたということである。 IIIN型 はFCR7000用，V型はFCR 9000用に開発されたもの であり，各装置でデータの読み取り部分やレーザプリ ンタ部，その他搬送系などすべてが異なる。したがっ て，各IPと合致したシステムで測定した性能と本実験 における結果とは異なっている可能性がある。また， 各装置とIPとの組合せを変化させたときや，レーザの
出力を変えたときなどの特性もさらに測定する 必要があろう。

\section{4. まとめ}

FCRシステムの検出器であるIPは，I型から最 新のV型までいろいろな点が改良されてきた。 マンモグラフィ専用であるHRシリーズ，一般撮 影用のSTシリーズについて，それぞれ III 型以降 のIPの基本的な物理特性を測定した。 その結果,

1. $\mathrm{HR}, \mathrm{ST}$ と各タイプの解像特性に変化は 認められなかった。

2.HRでは, III 型より IIIN型の照射線量減弱率 が䄪 $10 \%$ 増加し，粒状特性も改善されてい たが，V型になると IIIN型より減弱率は低 下したものの，粒状特性はさらに向上して いた。

3.STについては, III，III^型の照射線量減弱 率はほほ同等で，V型だけ約10\%増加して いた，粒状特性は，V型が改善されていた が，III 型は IIIN，V 型と比べて構造モトル が明らかに異なっていた。

甜

プリサンプリングMTF及びディジタルWSの測定に 関して, 藤田広志博士(岐阜大学工学部電子情報工学 科)に，ご協力いただきましたことを深謝いたしま す.

\section{参考文献}

1) 中島延淑, 武尾英哉, 石田正光, 他：FCRシステムの濃度 /画像レンジ自動設定機能(EDR)。富士メディカルレビュ 一, No.2, 34-48, (1993).

2）松田照美，荒川 哲，幸田勝博，他：New FCR: FCR9000 の新技術開発。富士メディカルレビュー, No.1,47-64, (1993).

3）杜下淳次, 藤田広志, 大塚昭義, 他：コンピューテッドラ ジオグラフィの基礎的な物理特性. 日放技学誌，46(6), 824-830, (1990).

4) Fujita $H$, Tsai DY, Itoh $T$, et al: A Simple Method for Determining the Modulation Transfer Function in Digital Radiography. IEEE TRANSACTION ON MEDICAL IMAGING, 11 (1), 34-39, (1992)

5) 藤田広志, 他：ディジタルラジオグラフィの画像評洒 $<3$. ウィナースペクミル>。日放技学誌，48(6)，925-936, (1992).

6) James TD. III, David LE, Lois R, et al: DQE (f) of four generations of computed radiography acquisition devices. Med.Phys., 22 (10\%, 1581-1593, (1995)

7) 藤川津義, 上田克彦, 大塚昭義, 他：パーソナルコンピュ 一タによるFCR-101画像データの読み取り。医画情誌，5
(2), 82-86, (1988).

8) 藤田広志, 他：ディジタルラジオグラフィーの画像評価< 2. MTF>. 日放技学誌, 47(4),653-669, (1991).

9) Fujita H, Morishita J, Ueda K, et al: Resolution Properties of a Computed Radiographic System., Proc. of SPIE (Medical Imaging III: Image Formation), 1090, 263-275, (1989).

10) Fujita H, Ueda K, Morishita J, et al: Basic Imaging Properties of a Computed Radiographic System with Photostimulable Phosphors. Med. Phys., 16, 52-59, (1990).

11) 畑川政勝, 井上誠, 庄垣雅史, 他：ディジタル系におけ るMTFの娭討(ファイナルMTFおよびオーバーオールエリ アシング)。目放技学誌，48(11)，1932-1938，(1992）。

12) 井上誠, 中村 敦, 小川隆由, 他: 矩形波チャート法に よるCRのMTF測定. 日放技学誌，52(9)，1244，(1996).

13) 高野正雄: 5. 放射線医療画像の解析に関方問題点とその 展望ーアナログX線写真系とデジタルX線写真系一。日放 技学誌，40(2)，272-277，(1984).

14）松尾 悟, 野間和夫, 木田哲生, 他：胸部 $X$ 線写真の標準 化へのアプローチ 視覚評価と物理評価の関係について(第 1 報)。日放技学誌，52(9), 1247，(1996)。 